\title{
PERENCANAAN PENINGKATAN KUALITAS JASA PELAYANAN PERPUSTAKAAN DENGAN METODE REKAYASA NILAI
}

\author{
Dyah Retno $\mathbf{P}^{1}$
}

\begin{abstract}
A quality of service in UPT. Centre Library Muhammadiyah University of Malang especially in user devision and human resources management division is one of most used division which is complaint by users and need to increase of quality to satisfy users. Value engineering is a method which solue this problem ti increase the quality service with keeping the rule of customer satisfaction.

Based on the analysis with implement value engineering can be found the initial value design about $\mathrm{I}$ and advised design about 1,045 in other hand the initial design performance give about 45,799 and advised design about 51,488 . It means that there is an increasing $4,5 \%$ of value and $12,421 \%$ of performance.
\end{abstract}

Key Words : Value Engineering, FAST, Matrix

\section{PENDAHULUAN}

Keberadaan sistem jasa

pelayanan yang ada selama ini berdasarkan pengamatan ternyata masih terdapat banyak keluhan dari para pengguna, baik dari pelayanan yang diberikan oleh pengelola maupun dari prosedur pelayanannya. Berakar dari keluhan para pengguna yang ada, maka peneliti mengambil kesimpulan bahwa kualitas jasa pelayanan masih harus ditingkatkan lagi. Untuk itulah peneliti akan menggunakan metode rekayasa nilai.

Rekayasa Nilai merupakan salah satu metode yang bisa digunakan dalam usaha meningkatkan kualitas jasa pelayanan dengan tetap berpedoman pada kepentingan dan keinginan para user atau customer. Dalam hal ini peneliti mengambil obyek penelitian Jasa Pelayanan di UPT Perpustakaan Pusat Universitas
Muhammadiyah Malang dengan tujuan memperoleh desain alternatif sistem pelayanan terbaik pada bagian jasa pengguna dan bagian Manajemen Sumber Daya Manusia sesuai dengan kepentingan dan keinginan para pengguna perpustakaan. Dan menganalisa struktur biaya yang digunakan untuk setiap desain alternatif serta meningkatkan nilai (value) jasa pada UPT Perpustakaan Pusat UMM.

\section{TINJAUAN PUSTAKA}

\section{Pengertian Kualitas}

Banyak usaha yang telah
dirumuskan para pakar untuk mendefinisikan kualitas jasa atau pelayanan, agar dapat didesain, dikendalikan, dan dikelola sebagaimana halnya dengan kualitas barang. 
$\begin{array}{cccc}\text { Definisi } & \text { Kualitas } & \text { menurut } \\ \text { Vincent } & \text { Gaspersz, } & \text { (Manajemen } & \text { Kualitas }\end{array}$ Dalam Industri Jasa, hal : 125) adalah :

"Kualitas merupakan totalitas dari features dan karakteristik barang dan jasa yang menunjang kemampuannya untuk memenuhi persyaratan kebutuhan."

\section{Karakteristik Jasa}

Persyaratan dari suatu jasa perlu didefinisikan secara jelas dalam bentuk karakteristik-karakteristik yang dapat diamati dan merupakan subyek terhadap evaluasi pelanggan.

Adapun karakteristik jasa adalah sebagai berikut :

1. Karakteristik jasa dan penyerahan jasa harus didefinisikan secara jelas.

2. Merupakan subyek terhadap evaluasi pelanggan.

3. Karakteristik proses yang mengendalikan jasa harus didefinisikan secara jelas.

4. Karakteristik jasa dan penyerahan jasa dapat bersifat kuantitatif (dapat diukur) atau kualitatif (dapat diperbandingkan).

\section{Definisi Perpustakaan}

Definisi perpustakaan menurut Dr. Kusmijati dan Drs. Hendra Dinama (Pedoman Mengelola Perpustakaan, Secara Praktis, 1996, hal : 1) adalah suatu unit kerja yang mempunyai tugas mengumpulkan bahan pustakan yang sesuai dengan kebutuhan pemakainya, mengolah dan menyajikan koleksi beserta sarana penelusurannya secara sistematis, dan memberikan jasa pemanfaatan koleksi dan penelusuran informasi.

Perpustakaan pada umumnya merupakan unit pelaksana yang bertugas menyediakan kebutuhan bahan pustaka, dokumen, dan informasi yang berkaitan dengan kegiatan instansi / lembaga / organisasi yang membawahi perpustakaan, demi menunjang pelaksanaan tugas dalam instansi / lembaga / organisasi tersebut.

\section{Definisi dan Pengertian Rekayasa Nilai}

Pada dasarnya Rekayasa Nilai menjelaskan studi teknik dari suatu proyek yang sedang dikembangkan. Secara lebih jelas, Rekayasa Nilai (Value Engineering) merupakan pendekatan sistematik dengan menggunakan teknik-teknik tertentu untuk :

1. Mengidentifikasikan fungsi-fungsi yang diperlukan.

2. Menerapkan nilai-nilainya.

3. Mengembangkan alternatif-alternatif.

Di dalam studi Rekayasa Nilai kita akan mengenal jenis-jenis nilai yang dipertimbangkan dalam proses perancangan. Adapun nilai-nilai tersebut adalah :

1. Nilai Guna (Use Value)

2. Nilai Kebanggaan (Esteem Value)

3. Nilai Tukar (Exchange Value)

4. Nilai Biaya (Cost Value)

Nilai (value) dapat dirumuskan sebagai ratio (perbandingan) antara performansi yang ditampilkan oleh suatu fungsi terhadap biaya yang dikeluarkan untuk mendapatkan fungsi tersebut.

Dimana rumus untuk Value adalah : 
Value $=\frac{\text { Performansi }}{\text { Biaya }}$

$\begin{array}{lll}\text { Performansi }: & \text { keuntungan atau } \\ & \text { manfaat yang diperoleh } \\ & \text { dari fungsi-fungsi suatu } \\ & \text { produk/jasa } & \\ \text { Biaya } \quad \text { biaya total yang } \\ & \text { dikeluarkan untuk } \\ & \text { mendapatkan fungsi } \\ & \text { yang dinginkan. }\end{array}$

Ada beberapa usaha untuk meningkatkan nilai, antara lain :

* Menurunkan biaya dan performansi, dimana penurunan performansi lebih kecil dibandingkan penurunan biaya (A).

* Performansi tetap, biaya diturunkan (B)

* Performansi naik, biaya diturunkan (C)

* Performansi naik, biaya tetap (F)

* Menaikkan performansi dan biaya, dimana kenaikan performansi lebih besar dibandingkan dengan kenaikan biaya (I)

\section{Tabel 1}

Performansi Terhadap Biaya

\begin{tabular}{|c|c|c|c|c|}
\hline & \multicolumn{3}{|c|}{ Performansi } \\
\hline & & Turun & Tetap & Naik \\
\hline \multirow{3}{*}{ Biaya } & Turun & $\mathrm{A}$ & B & $\mathrm{C}$ \\
\hline & Tetap & D & $E$ & $\mathrm{~F}$ \\
\hline & Naik & G & $\mathrm{H}$ & I \\
\hline
\end{tabular}

\section{Pengertian Fungsi dan Kriteria}

Fungsi pada dasarnya dapat diartikan sebagai kegunaan atau manfaat yang diberikan oleh jasa kepada pemakainya untuk memenuhi suatu atau sekumpulan kebutuhan tertentu. Secara umum fungsi dapat dibedakan atas dua jenis antara lain :

1. Fungsi Dasar (Primer)

2. Fungsi Pendukung (Sekunder)

\section{Tahap-Tahap Kerja Rekayasa Nilai}

Dimana Rencana Kerja Rekayasa Nilai terdiri dari lima tahap, yaitu :

1. Tahap Informasi

2. Tahap Kreatif

3. Tahap Analisa / Evaluasi

4. Tahap Pengembangan

5. Tahap Rekomendasi

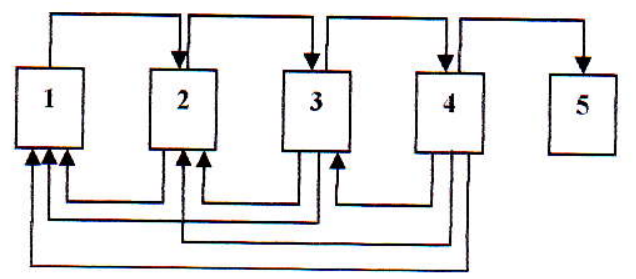

Gambar 1

\section{Skema Rencana Kerja Rekayasa Nilai}

\section{Fase Informasi (Information Phase)}

Informasi yang diperlukan untuk setiap nilai berbeda untuk setiap proyek, namun secara umum dapat dituliskan antara lain :

* Kriteria Desain (kebutuhan sistem)

* Kondisi lapangan (topografi, keadaan tanah, daerah sekitar dan foto-foto udara)

* Peraturan-peraturan

* Elemen-elemen desain (bagianbagian proses, komponenkomponen konstruksi)

* Sejarah proyek

* Batasan-batasan yang ditetapkan pada proyek 
Fasilitas-fasilitas yang tersedia

* Syarat yang timbul akibat partisipasi masyarakat (misal : faktor keamanan pekerja)

* Perhitungan-perhitungan desain

Teknik-teknik yang dapat digunakan dalam tahap informasi ini adalah
* Kuisioner
* Peramalan
* Wawancara
* Metode Delphi
* Riset Pasar
* FAST (Functional Analysis System Technique)

\section{Fase Kreatif (Creatif Phase)}

Teknik yang dapat dipakai di sini dapat dibedakan menjadi dua kelompok, yaitu

- Analitik dan mekanistik
a. Analisa morfologi
b. Check list
c. Matrik input - output (black $b o x)$

* Psiko sosial (memanfaatkan dinamika kelompok, kelebihan yang dimiliki karena adanya kelompok)
a. Brainstorming
b. Sinektik

\section{Fase Analisa (Judgement Phase)}

Fase ini merupakan fase evaluasi terhadap alternatif-alternatif yang dihasilkan dari fase kreatif, sehingga dengan demikian dapat diketahui alternatif mana yang akan digunakan untuk studi selanjutnya

\section{Fase Pengembangan}

$$
\text { Langkah-langkah }
$$

dilakukan pada tahap pengembangan ini antara lain :

1. Membandingkan desain

2. Menuliskan desain awal atau desain usulan

3. Membandingkan analisa biaya

4. Mendiskusikan keuntungan dan kerugian desain yang direkomendasikan

5. Mendiskusikan implikasi dan kebutuhan dalam pelaksanaan desain yang direkomendasikan

\section{Fase Rekomendasi}

\section{Teknik-Teknik dalam Rekayasa Nilai}

Beberapa teknik yang dipakai pada tahap-tahap perencanaan Rekayasa Nilai antara lain :

Tabel 2

Teknik yang Digunakan dalam Rekayasa Nilai

\begin{tabular}{|c|c|}
\hline Tahap & $\begin{array}{c}\text { Teknik yang } \\
\text { Dipakai }\end{array}$ \\
\hline Informasi & $\begin{array}{l}\text { Metode Questioner } \\
\text { Wawancara } \\
\text { Riset Pasar }\end{array}$ \\
\hline Kreatif & $\begin{array}{l}\text { Analisa Morfologis } \\
\text { Brainstorming } \\
\text { Check List } \\
\text { Metode FAST }\end{array}$ \\
\hline Analisa & $\begin{array}{l}\text { Analisa Adjective } \\
\text { Analisa Hierarki } \\
\text { Matriks Zero One } \\
\text { Matriks Evaluasi }\end{array}$ \\
\hline
\end{tabular}




\section{Metode FAST}

Istilah yang digunakan dalam

Metode FAST adalah sebagai berikut :

1. Fungsi Utama / Dasar

2. Fungsi Pendukung

3. Fungsi Tidak Perlu

4. Fungsi Level Lebih Tinggi

5. Fungsi Level Lebih Rendah

\section{Analisa Hierarki Proses}

Dalam memecahkan persoalan proses hierarki analitik memakai 3 prinsip, yaitu :

1. Prinsip menyusun hierarki

2. Prinsip menyusun prioritas

3. Prinsip konsistensi logis

Proses Hierarki Analitik dilakukan dengan langkah-langkah sebagai berikut :

1. Penyusunan Struktur Hierarki

2. Penilaian Perbandingan Berpasangan

Tabel 3

Matriks Perbandingan Berpasangan - AHP

\begin{tabular}{|c|c|c|c|c|c|c|}
\cline { 2 - 7 } \multicolumn{1}{c|}{} & $\mathbf{K}_{\mathbf{1}}$ & $\mathbf{K}_{\mathbf{2}}$ & $\mathbf{K}_{\mathbf{3}}$ & $\mathbf{K}_{\mathbf{4}}$ & & $\mathbf{K}_{\mathbf{n}}$ \\
\hline $\mathbf{K}_{\mathbf{1}}$ & 1 & $\mathrm{~N} 1$ & $\mathrm{~N} 2$ & $\mathrm{~N} 4$ & $\ldots$ & $\mathrm{Nj}-4$ \\
$\mathbf{K}_{\mathbf{2}}$ & $1 / \mathrm{N} 1$ & 1 & $\mathrm{~N} 3$ & $\mathrm{~N} 5$ & $\ldots$ & $\mathrm{Nj}-3$ \\
$\mathbf{K}_{\mathbf{3}}$ & $1 / \mathrm{N} 2$ & $1 / \mathrm{N} 3$ & 1 & $\mathrm{~N} 6$ & $\ldots$ & $\mathrm{Nj}-2$ \\
$\mathbf{K}_{\mathbf{4}}$ & $1 / \mathrm{N} 4$ & $1 / \mathrm{N} 5$ & $1 / \mathrm{N} 6$ & 1 & $\ldots$ & $\mathrm{Nj}-1$ \\
$\mathbf{K}_{\mathbf{n}}$ & $1 / \mathrm{Nj}-4$ & $1 / \mathrm{Nj}-3$ & $1 / \mathrm{Nj}-2$ & $1 / \mathrm{Nj}-1$ & $\ldots$ & $1 / \mathrm{Nj} 1$ \\
\hline
\end{tabular}

\section{Dimana :}

$\mathrm{K}$ : elemen yang akan dibandingkan

$\mathrm{N}$ : entri, nilai skala $1-9$

$\mathrm{n} \quad$ : banyaknya elemen yang dibandingkan

\section{Menghitung Eigen Vektor dan Eigen}

Value

\section{Uji Konsistensi Data}

Uji konsistensi data diketahui

dari CR (Consistency Ratio) yang

merupakan hasil bagi antara CI (Consistensy

Indeks) dan RI (Random Indeks) seperti

rumus berikut ini : $\mathrm{CR}=\frac{\mathrm{CI}}{\mathrm{RI}}$, dimana $\mathrm{CI}$
(Consistensy Indeks) dapat diperoleh dari :

$$
\mathrm{CI}=\frac{\mathrm{X}_{\text {maks }}-\mathrm{n}}{(\mathrm{n}-1)}
$$

Dimana :

$\mathrm{X}_{\text {maks }} \quad$ : Matriks Eigen Value

n

Parameter untuk mengukur konsistensi pembanding

Analisa yang dapat diambil adalah bila :

$$
\begin{aligned}
& \mathrm{CR}<0,10 \quad=\quad \text { konsisten } \\
& \mathrm{CR} \geqslant 0,10=\text { tidak konsisten }
\end{aligned}
$$

Tabel 4

Random Indeks (RI)

\begin{tabular}{|c|c|}
\hline Matriks Ordo & Indeks Random \\
\hline 1 & 0,00 \\
\hline 2 & 0,00 \\
\hline 3 & 0,58 \\
\hline 4 & 0,90 \\
\hline 5 & 1,12 \\
\hline 6 & 1,24 \\
\hline
\end{tabular}




\begin{tabular}{|l|l|}
\hline 7 & 1,31 \\
\hline 8 & 1,41 \\
\hline 9 & 1,45 \\
\hline 10 & 1,49 \\
\hline 11 & 1,51 \\
\hline
\end{tabular}

\section{Analisa Morfologis}

Jika suatu masalah hanya mempunyai 2 elemen, model ini dengan mudah dapat divisualisasikan dalam dua sumbu pembangkit alternatif berbentuk bidang datar. Sumbu horizontalnya merupakan satu elemen yang dibagi lagi menjadi beberapa atribut. Sumbu vertikalnya merupakan elemen lainnya dan dengan cara yang sama dibagi dalam atribut-atribut. Kemudian atribut-atribut dari masingmasing elemen dikombinasikan dan akan menghasilkan alternatif solusi. Jika masalah tersebut terdiri dari 3 elemen modelnya akan berupa 3 sumbu pembangkit alternatif yang berbentuk ruang tiga dimensi.

\section{Matriks Evaluasi}

Keuntungan yang diperoleh oleh Metode Matriks Evaluasi ini adalah :

1. Dapat digunakan untuk memecahkan altematif yang multi kriteria.

2. Masing-masing kriteria dapat berbeda tingkat kepentingannya (dinyatakan dengan bobot)

Cara melaksanakan metode ini aalah sebagai berikut :

1. Menetapkan alternatif-alternatif solusi yang mungkin.

2. Menetapkan kriteria-kriteria yang berpengaruh.

3. Menentukan bobot masing-masing kriteria.
4. Memberikan penilaian untuk setiap alternatif masing-masing kriteria.

5. Menghitung nilai total untuk masingmasing alternatif.

\section{Memilih alternatif dengan nilai total yang terbesar}

Tabel 5

Matriks Evaluasi

\begin{tabular}{|c|c|c|c|c|c|c|}
\hline Alternatif & \multicolumn{4}{|c|}{ Matriks Evaluasi } & \multicolumn{1}{|c|}{ Nilai } \\
Terpitith & Q1 & Q2 & Q3 & Q.. & Qn & Total \\
\hline Alternatif 1 & & & & & & \\
Altematif 2 & & & & & & \\
Alternatif 3 & & & & & & \\
... & & & & & & \\
Alternatif n & & & & & & \\
\hline
\end{tabular}

\section{METODOLOGI PENELITIAN}

Data yang diperlukan dalam analisa ini antara lain :

Tabel 6

Penilaian Responden Terhadap Perencanaan

Peningkatan Kualitas Jasa

\begin{tabular}{|c|c|c|c|c|c|c|}
\hline \multirow{2}{*}{$\begin{array}{l}\text { Respon- } \\
\text { den }\end{array}$} & \multicolumn{6}{|c|}{ Kriteria } \\
\hline & 1 & 2 & 3 & 4 & 5 & 6 \\
\hline 1. & 1 & 8 & 5 & 5 & 5 & 7 \\
\hline 2. & 6 & 7 & 6 & 5 & 6 & 7 \\
\hline 3. & 7 & 5 & 7 & 8 & 7 & 6 \\
\hline 4. & 6 & 3 & 4 & 4 & 3 & 2 \\
\hline 5. & 4 & 3 & 4 & 4 & 4 & 3 \\
\hline 6. & 4 & 5 & 8 & 8 & 7 & 9 \\
\hline 7. & 7 & 9 & 8 & 9 & 9 & 8 \\
\hline 8. & 5 & 5 & 4 & 8 & 6 & 7 \\
\hline 9. & 7 & 6 & 7 & 5 & 8 & 8 \\
\hline 10. & 9 & 6 & 6 & 8 & 8 & 8 \\
\hline 11. & 7 & 5 & 4 & 8 & 5 & 6 \\
\hline 12. & 5 & 3 & 2 & 3 & 4 & 3 \\
\hline 13. & 5 & 5 & 5 & 8 & 5 & 2 \\
\hline 14. & 7 & 5 & 5 & 6 & 7 & 5 \\
\hline 15. & 6 & 6 & 6 & 7 & 5 & 6 \\
\hline 16. & 6 & 5 & 5 & 4 & 5 & 4 \\
\hline 17. & 5 & 4 & 4 & 10 & 4 & 2 \\
\hline 18. & 7 & 5 & 6 & 6 & 6 & 6 \\
\hline 19. & 5 & 4 & 8 & 9 & 6 & 7 \\
\hline 20. & 6 & 5 & 7 & 8 & 8 & 7 \\
\hline 21. & 9 & 7 & 4 & 5 & 5 & 2 \\
\hline 22. & 7 & 5 & 4 & 2 & 7 & 5 \\
\hline 23. & 6 & 6 & 8 & 7 & 8 & 8 \\
\hline
\end{tabular}




\begin{tabular}{|c|c|c|c|c|c|c|}
\hline 24. & 8 & 5 & 6 & 3 & 6 & 8 \\
\hline 25. & 6 & 7 & 8 & 8 & 8 & 6 \\
\hline 26. & 9 & 5 & 3 & 7 & 4 & 3 \\
\hline 27. & 7 & 6 & 5 & 5 & 6 & 5 \\
\hline 28. & 8 & 9 & 9 & 10 & 10 & 8 \\
\hline 29. & 8 & 8 & 8 & 6 & 8 & 8 \\
\hline 30. & 7 & 5 & 8 & 8 & 5 & 8 \\
\hline 31. & 9 & 9 & 8 & 9 & 8 & 9 \\
\hline 32. & 9 & 5 & 8 & 10 & 8 & 9 \\
\hline 33. & 7 & 9 & 9 & 9 & 5 & 7 \\
\hline 34. & 5 & 5 & 5 & 5 & 5 & 5 \\
\hline 35. & 6 & 9 & 9 & 6 & 6 & 8 \\
\hline 36. & 7 & 8 & 6 & 8 & 7 & 7 \\
\hline 37. & 7 & 7 & 8 & 6 & 9 & 9 \\
\hline 38. & 6 & 7 & 6 & 2 & 6 & 7 \\
\hline 39. & 8 & 7 & 7 & 5 & 9 & 8 \\
\hline 40. & 8 & 6 & 7 & 5 & 8 & 5 \\
\hline 41. & 5 & 5 & 5 & 9 & 9 & 7 \\
\hline 42. & 9 & 7 & 4 & 8 & 2 & 3 \\
\hline 43. & 8 & 9 & 6 & 7 & 7 & 8 \\
\hline 44. & 5 & 5 & 4 & 5 & 6 & 4 \\
\hline 45. & 4 & 4 & 4 & 6. & 5 & 5 \\
\hline 46. & 7 & 4 & 3 & 8 & 5 & 5 \\
\hline 47. & 3 & 5 & 3 & 5 & 4 & 7 \\
\hline 48. & 9 & 9 & 5 & 10 & 9 & 8 \\
\hline 49. & 5 & 3 & 7 & 2 & 7 & 8 \\
\hline 50. & 8 & 3 & 7 & 4 & 6 & 8 \\
\hline 51. & 7 & 8 & 4 & 6 & 8 & 5 \\
\hline 52. & 7 & 7 & 8 & 7 & 8 & 8 \\
\hline 53. & 5 & 6 & 5 & 7 & 6 & 4 \\
\hline 54. & 9 & 6 & 7 & 10 & 5 & 3 \\
\hline 55. & 7 & 5 & 8 & 6 & 9 & 7 \\
\hline 56. & 8 & 6 & 7 & 9 & 8 & 6 \\
\hline 57. & 9 & 4 & 6 & 4 & 3 & 3 \\
\hline 58. & 6 & 7 & 3 & 4 & 5 & 6 \\
\hline 59. & 9 & 7 & 7 & 9 & 6 & 5 \\
\hline 60. & 7 & 4 & 5 & 7 & 6 & 6 \\
\hline 61. & 8 & 7 & 6 & 1 & 8 & 5 \\
\hline 62. & 6 & 6 & 7 & 5 & 6 & 5 \\
\hline 63. & 8 & 8 & 6 & 7 & 6 & 6 \\
\hline 64. & 6 & 6 & 9 & 6 & 7 & 5 \\
\hline 65. & 8 & 6 & 6 & 6 & 6 & 7 \\
\hline 66. & 7 & 5 & 5 & 5 & 6 & 5 \\
\hline 67. & 8 & 4 & 5 & 8 & 7 & 7 \\
\hline 68. & 6 & 6 & 7 & 6 & 6 & 7 \\
\hline 69. & 6 & 3 & 7 & 5 & 5 & 6 \\
\hline 70. & 7 & 5 & 5 & 5 & 5 & 4 \\
\hline 71. & 4 & 4 & 6 & 3 & 7 & 8 \\
\hline 72. & 6 & 8 & 5 & 5 & 7 & 4 \\
\hline 73. & 8 & 6 & 7 & 9 & 6 & 7 \\
\hline 74. & 9 & 4 & 5 & 9 & 9 & 5 \\
\hline 75. & 8 & 7 & 7 & 5 & 7 & 8 \\
\hline 76. & 9 & 7 & 7 & 9 & 5 & 8 \\
\hline 77. & 10 & 8 & 7 & 5 & 5 & 9 \\
\hline 78. & 5 & 7 & 5 & 4 & 7 & 8 \\
\hline 79. & 8 & 4 & 2 & 3 & 9 & 10 \\
\hline 80. & 7 & 5 & 6 & 6 & 6 & 5 \\
\hline 81. & 9 & 3 & 5 & 5 & 7 & 3 \\
\hline 82. & 10 & 5 & 4 & 9 & 3 & 8 \\
\hline 83. & 8 & 7 & 7 & 6 & 5 & 9 \\
\hline 84. & 8 & 5 & 7 & 9 & 8 & 7 \\
\hline
\end{tabular}

\begin{tabular}{|c|c|c|c|c|c|c|}
\hline $\mathbf{8 5 .}$ & 9 & 8 & 5 & 8 & 4 & 3 \\
\hline $\mathbf{8 6 .}$ & 7 & 4 & 6 & 6 & 7 & 7 \\
\hline $\mathbf{8 7 .}$ & 10 & 7 & 10 & 7 & 9 & 8 \\
\hline $\mathbf{8 8 .}$ & 8 & 6 & 8 & 7 & 6 & 9 \\
\hline $\mathbf{8 9 .}$ & 9 & 8 & 5 & 6 & 6 & 10 \\
\hline $\mathbf{9 0 .}$ & 6 & 6 & 8 & 7 & 10 & 5 \\
\hline $\mathbf{9 1 .}$ & 8 & 8 & 8 & 4 & 6 & 5 \\
\hline $\mathbf{9 2 .}$ & 3 & 6 & 5 & 10 & 7 & 8 \\
\hline $\mathbf{9 3 .}$ & 7 & 1 & 9 & 6 & 8 & 4 \\
\hline $\mathbf{9 4 .}$ & 7 & 7 & 7 & 5 & 3 & 7 \\
\hline $\mathbf{9 5 .}$ & 8 & 3 & 3 & 3 & 9 & 3 \\
\hline $\mathbf{9 6 .}$ & 2 & 7 & 5 & 4 & 4 & 4 \\
\hline $\mathbf{9 7 .}$ & 8 & 6 & 6 & 8 & 4 & 8 \\
\hline $\mathbf{9 8 .}$ & 10 & 2 & 10 & 6 & 9 & 6 \\
\hline $\mathbf{9 9 .}$ & 5 & 4 & 8 & 8 & 8 & 7 \\
\hline $\mathbf{1 0 0 .}$ & 7 & 8 & 9 & 5 & 9 & 6 \\
\hline $\boldsymbol{\Sigma}$ & \multirow{2}{*}{692} & 580 & 610 & 633 & 642 & 620 \\
\hline
\end{tabular}

Adapun langkah-langkah dalam penelitian ini antara lain :

1. Tahap Informasi

2. Tahap Kreatif

3. Tahap Analisa

4. Tahap Pengembangan

5. Tahap Rekomendasi

\section{HASIL DAN PEMBAHASAN}

1. BKA (Batas Kontrol Atas) $=\bar{x}+3 \delta$

BKB (Batas Kontrol Bawah) $=\bar{x}-3 \delta$

2. $\mathrm{N}=\left[\frac{\mathrm{k} / 2 \sqrt{\mathrm{N}} \Sigma(\mathrm{X})^{2}-\left(\sum \mathrm{X}\right)^{2}}{\sum \mathrm{X}}\right]$

3. $\%$ Kriteria $(\mathrm{KI})=\frac{\mathrm{KI}}{\sum \mathrm{KI}} \times 100 \%$

Adapun hasil perhitungan untuk penentuan tingkat kontribusi masing-masing kriteria adalah sebagaimana terlihat pada tabel berikut : 
Tabei 7

Perhitungan Rata-rata dan Standart Deviasi

\begin{tabular}{|c|c|c|c|c|c|}
\hline No & Kriteria & $\begin{array}{c}\text { Nilai Rata } \\
(\mathrm{x})^{2}\end{array}$ & $\begin{array}{c}\text { Standart } \\
\text { Deviasi } \\
(\delta \mathbf{X})\end{array}$ & $\begin{array}{c}\text { Batas Kontrol } \\
\text { Atas } \\
\text { (BKA) }\end{array}$ & $\begin{array}{l}\text { Batas Kontrol } \\
\text { Bawah } \\
\text { (BKB) }\end{array}$ \\
\hline 1 & Keadaan ruangan perpustakaan & 18,32 & 1,7589 & 12,1967 & 1,6433 \\
\hline 2 & Waktu pelayanan & 15,36 & 1,7493 & 11,0479 & 0,5521 \\
\hline 3 & Ketepatan pelayanan & 16,15 & 1,7748 & 11,4244 & 0,7756 \\
\hline 4 & $\begin{array}{l}\text { Adanya fasilitas penunjang yang } \\
\text { presentatif }\end{array}$ & 16,76 & 2,1026 & 12,6378 & 0,0222 \\
\hline 5 & Kualitas Sumber Daya Manusia & 17,00 & 1,7446 & 11,6538 & 1,1862 \\
\hline 6 & Keluasan jaringan layanan informasi & 16,42 & 1,9799 & 12,1397 & 0,2603 \\
\hline \multicolumn{2}{|r|}{ Total } & 100 & - & - & - \\
\hline
\end{tabular}

Tabel 8

\section{Nilai Kontribusi Masing-Masing Kriteria}

\begin{tabular}{|c|l|c|}
\hline No & \multicolumn{1}{|c|}{ Kriteria } & $\begin{array}{c}\text { Bobot } \\
(\mathbf{\%})\end{array}$ \\
\hline 1 & Keadaan ruangan & 18,32 \\
& perpustakaan & 15,36 \\
2 & Waktu pelayanan & 16,15 \\
3 & Ketepatan pelayanan & 16,76 \\
5 & Adanya fasilitas penunjang & yang representatif \\
5 & Kualitas Sumber Daya & 17,00 \\
6 & $\begin{array}{l}\text { Manusia } \\
\text { Keluasan jaringan layanan } \\
\text { informasi }\end{array}$ & 16,42 \\
\hline
\end{tabular}

Tabei 9

Rangking Nilai Kontribusi Masingmasing Kriteria

\begin{tabular}{|c|l|c|}
\hline No & \multicolumn{1}{|c|}{ Kriteria } & $\begin{array}{c}\text { Bobot } \\
(\mathbf{\%})\end{array}$ \\
\hline 1 & Keadaan ruangan perpustakaan & 18,32 \\
2 & Kualitas Sumber Daya Manusia & 17,00 \\
3 & Adanya fasilitas penunjang & 16,76 \\
& yang representatif & 16,42 \\
4 & Keluasan jaringan layanan & informasi \\
5 & Ketepatan pelayanan & 16,15 \\
6 & Waktu pelayanan & 15,36 \\
\hline
\end{tabular}

\section{Pengujian Konsistensi Data}

1. Matriks Perbandingan Berpasangan

Tabei 10

Matriks Perbandingan Berpasangan

\begin{tabular}{|c|c|c|c|c|c|c|}
\hline Kriteria & $\mathbf{1}$ & $\mathbf{2}$ & $\mathbf{3}$ & $\mathbf{4}$ & $\mathbf{5}$ & $\mathbf{6}$ \\
\hline $\mathbf{1}$ & 1 & 3 & 3 & 5 & 5 & 7 \\
\hline $\mathbf{2}$ & $1 / 3$ & 1 & 3 & 3 & 5 & 5 \\
\hline $\mathbf{3}$ & $1 / 3$ & $1 / 3$ & 1 & 4 & 3 & 3 \\
\hline $\mathbf{4}$ & $1 / 5$ & $1 / 3$ & $1 / 4$ & 1 & 4 & 3 \\
\hline $\mathbf{5}$ & $1 / 5$ & $1 / 5$ & $1 / 3$ & $1 / 4$ & 1 & 3 \\
\hline $\mathbf{6}$ & $1 / 7$ & $1 / 5$ & $1 / 3$ & $1 / 3$ & $1 / 3$ & 1 \\
\hline
\end{tabular}

2. Matriks Eigen Vektor

Matriks Kolom Matriks Eigenvektor

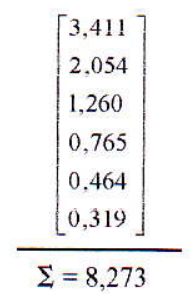

$$
\left[\begin{array}{l}
0,412 \\
0,248 \\
0,152 \\
0,092 \\
0,056 \\
0,039
\end{array}\right]
$$

3. Matriks Eigen Value

$\begin{array}{ccc}\text { Matriks Baru } & \text { Matriks } & \text { Matriks } \\ \text { Eigenvektor } & \text { Eigenvalue }\end{array}$

$$
\frac{\left[\begin{array}{l}
2,625 \\
1,592 \\
1,025 \\
0,636 \\
0,379 \\
0,248
\end{array}\right]}{\Sigma=6,504} \quad\left[\begin{array}{l}
0,412 \\
0,248 \\
0,152 \\
0,092 \\
0,056 \\
0,039
\end{array}\right] \quad \frac{\left[\begin{array}{l}
6,371 \\
6,419 \\
6,743 \\
6,913 \\
6,768 \\
6,333
\end{array}\right]}{\Sigma=6,504}
$$

$$
\begin{aligned}
\lambda \max & =\frac{\sum \text { Eigenvalue }}{\mathrm{n}} \\
& =\frac{39,547}{6}=6,591
\end{aligned}
$$

4. Menguji Konsistensi Data

Nilai Ratio Konsistensi (CR) yang merupakan hasil bagi antara Indeks Konsistensi (CI) dengan Indeks Random (IR) tingkat konsistensi jika $\mathrm{CR} \leqslant 0,100$ (Saaty, 1980), maka :

$$
\text { CI } \quad \begin{aligned}
& =\frac{\lambda \max -n}{n-1} \\
& =\frac{6,591-6}{5}=\frac{0,591}{5} \\
& =0,1182
\end{aligned}
$$




$$
\begin{aligned}
\mathrm{CR} & =\frac{\mathrm{CI}}{\mathrm{IR}} \\
\mathrm{CR} & =\frac{0,1182}{1,24}=0,095
\end{aligned}
$$

Sehingga dari hasil perhitungan di atas, data mempunyai tingkat konsistensi karena :

\section{Penentuan Bobot Fungsi}

Untuk mendapatkan bobot fungsi, disusun matriks perbandingan berpasangan dengan ordo yang sesuai dengan jumlah fungsi pada tingkatan hierarki yang sama.

1. Bobot Fungsi 221, 222, 223, 224, 225 , 226

\begin{tabular}{|c|c|c|c|c|c|c|}
\hline Fungsi & $\mathbf{2 2 1}$ & $\mathbf{2 2 2}$ & $\mathbf{2 2 3}$ & $\mathbf{2 2 4}$ & $\mathbf{2 2 5}$ & $\mathbf{2 2 6}$ \\
\hline $\mathbf{2 2 1}$ & 1 & 3 & 8 & 4 & 2 & 2 \\
$\mathbf{2 2 2}$ & $1 / 3$ & 1 & 6 & 3 & 3 & 2 \\
$\mathbf{2 2 3}$ & $1 / 8$ & $1 / 6$ & 1 & 8 & 3 & 3 \\
$\mathbf{2 2 4}$ & $1 / 4$ & $1 / 3$ & $1 / 8$ & 1 & 3 & 3 \\
$\mathbf{2 2 5}$ & $1 / 2$ & $1 / 3$ & $1 / 3$ & $1 / 3$ & 1 & 2 \\
$\mathbf{2 2 6}$ & $1 / 2$ & $1 / 2$ & $1 / 3$ & $1 / 3$ & $1 / 2$ & 1 \\
\hline
\end{tabular}

\begin{tabular}{c}
$\begin{array}{c}\text { Matriks } \\
\text { Kolom }\end{array}$ \\
{$\left[\begin{array}{l}2,696 \\
1,817 \\
1,070 \\
0,674 \\
0,577 \\
0,490\end{array}\right]$} \\
\hline$\Sigma=7,324$
\end{tabular}

2. Bobot Fungsi $221,222,223,224,225$

\begin{tabular}{|c|c|c|c|c|c|}
\hline Fungsi & $\mathbf{2 2 1}$ & $\mathbf{2 2 2}$ & $\mathbf{2 2 3}$ & $\mathbf{2 2 4}$ & $\mathbf{2 2 5}$ \\
\hline $\mathbf{2 2 1}$ & 1 & 5 & 3 & 3 & 3 \\
$\mathbf{2 2 2}$ & $1 / 5$ & 1 & 5 & 3 & 3 \\
$\mathbf{2 2 3}$ & $1 / 3$ & $1 / 5$ & 1 & 2 & 3 \\
$\mathbf{2 2 4}$ & $1 / 3$ & $1 / 3$ & $1 / 2$ & 1 & 2 \\
$\mathbf{2 2 5}$ & $1 / 3$ & $1 / 3$ & $1 / 3$ & $1 / 2$ & 1 \\
\hline
\end{tabular}

$\begin{array}{cc}\begin{array}{c}\text { Matriks } \\ \text { Kolom }\end{array} & \begin{array}{c}\text { Matriks } \\ \text { Eigenvektor }\end{array} \\ {\left[\begin{array}{c}2,667 \\ 1,552 \\ 0,833 \\ 0,644 \\ n \text { A n }\end{array}\right]} & {\left[\begin{array}{l}0,434 \\ 0,253 \\ 0,136 \\ 0,105 \\ 0,073\end{array}\right]}\end{array}$

$\Sigma=6,146$
3. Bobot Fungsi 131, 132, 133

\begin{tabular}{|c|c|c|c|}
\hline Fungsi & $\mathbf{1 3 1}$ & $\mathbf{1 3 2}$ & $\mathbf{1 3 3}$ \\
\hline $\mathbf{1 3 1}$ & 1 & 4 & 2 \\
$\mathbf{1 3 2}$ & $1 / 4$ & 1 & 4 \\
$\mathbf{1 3 3}$ & $1 / 2$ & $1 / 4$ & 1 \\
\hline
\end{tabular}

\section{Matriks}

Matriks

Kolom

Eigenvektor

$$
\frac{\left[\begin{array}{l}
2,000 \\
1,000 \\
0,500
\end{array}\right]}{\Sigma=3,500}
$$

4. Bobot Fungsi 121, 122, 123, 124

\begin{tabular}{|c|c|c|c|c|}
\hline Fungsi & $\mathbf{1 2 1}$ & $\mathbf{1 2 2}$ & $\mathbf{1 2 3}$ & $\mathbf{1 2 4}$ \\
\hline $\mathbf{1 2 1}$ & 1 & 5 & 4 & 2 \\
$\mathbf{1 2 2}$ & $1 / 5$ & 1 & 3 & 5 \\
$\mathbf{1 2 3}$ & $1 / 4$ & $1 / 3$ & 1 & 6 \\
$\mathbf{1 2 4}$ & $1 / 2$ & $1 / 5$ & $1 / 6$ & 1 \\
\hline
\end{tabular}

$$
\begin{gathered}
\begin{array}{c}
\text { Matriks } \\
\text { Kolom }
\end{array} \\
{\left[\begin{array}{c}
2,515 \\
1,316 \\
0,841 \\
1,359
\end{array}\right]} \\
\frac{\Sigma=5,031}{\Sigma}
\end{gathered}
$$

Matriks

Eigenvektor

5. Bobot Fungsi 111, 112, 113

\begin{tabular}{|c|c|c|c|}
\hline Fungsi & $\mathbf{1 1 1}$ & $\mathbf{1 1 2}$ & $\mathbf{1 1 3}$ \\
\hline $\mathbf{1 1 1}$ & 1 & 3 & 2 \\
$\mathbf{1 1 2}$ & $1 / 3$ & 1 & 2 \\
$\mathbf{1 1 3}$ & $1 / 2$ & $1 / 2$ & 1 \\
\hline
\end{tabular}

$$
\text { Matriks }
$$

Kolom

Matriks

$$
\left[\begin{array}{l}
0,500 \\
0,262 \\
0,167 \\
0,071
\end{array}\right]
$$

$$
\frac{\left[\begin{array}{l}
1,817 \\
0,874 \\
0,630
\end{array}\right]}{\Sigma=3,321}
$$

6. Bobot Fungsi 21, 22

\begin{tabular}{|c|c|c|}
\hline Fungsi & $\mathbf{2 1}$ & $\mathbf{2 2}$ \\
\hline $\mathbf{2 1}$ & 1 & 5 \\
$\mathbf{2 2}$ & $1 / 5$ & 1 \\
\hline
\end{tabular}




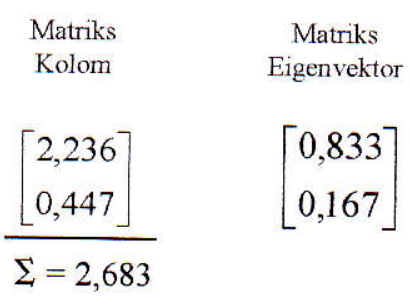

7. Bobot Fungsi 11, 12, 13

\begin{tabular}{|c|c|c|c|}
\hline Fungsi & $\mathbf{1 1}$ & $\mathbf{1 2}$ & $\mathbf{1 3}$ \\
\hline $\mathbf{1 1}$ & 1 & 3 & 3 \\
$\mathbf{1 2}$ & $1 / 3$ & 1 & 3 \\
$\mathbf{1 3}$ & $1 / 3$ & $1 / 3$ & 1 \\
\hline
\end{tabular}

$$
\begin{array}{cc}
\begin{array}{c}
\text { Matriks } \\
\text { Kolom }
\end{array} & \begin{array}{c}
\text { Matriks } \\
\text { Eigenvektor }
\end{array} \\
\frac{\left[\begin{array}{c}
2,080 \\
1,000 \\
0,481
\end{array}\right]}{\Sigma=3,561} & {\left[\begin{array}{l}
0,584 \\
0,281 \\
0,135
\end{array}\right]}
\end{array}
$$

\section{Bobot Fungsi 1, 2}

\begin{tabular}{|c|c|c|}
\hline Fungsi & $\mathbf{1}$ & $\mathbf{2}$ \\
\hline $\mathbf{1}$ & 1 & 2 \\
$\mathbf{2}$ & $1 / 2$ & 1 \\
\hline
\end{tabular}

$$
\begin{array}{cc}
\begin{array}{c}
\text { Matriks } \\
\text { Kolom }
\end{array} & \begin{array}{c}
\text { Matriks } \\
\text { Eigenvektor }
\end{array} \\
{\left[\begin{array}{c}
1,414 \\
0,707
\end{array}\right]} & {\left[\begin{array}{l}
0,667 \\
0,333
\end{array}\right]} \\
\hline \Sigma=2,121 &
\end{array}
$$

\section{KESIMPULAN}

Dari hasil analisa dapat disimpulkan bahwa :

1. Desain alternatif sistem pelayanan terbaik perpustakaan yang direkomendasikan adalah :

a. Bagian Sumber Daya Manusia
* Ricek dan sensor buku dilakukan di tempat yang sama

* Komunikasi harmonis antara pengelola dan pengguna

* Keramahtamahan pengelola perpustakaan

* Pelayanan yang cepat dan tepat

b. Bagian Jasa Pengguna

* Penghargaan terhadap pegawai yang berprestasi

* Jadwal kerja dan evaluasi secara berkala

* Katalog buku secara manual

* Katalog buku dengan komputerisasi (1 komputer)

* Peminjaman buku sumbangan dan skripsi dengan batas waktu 2 - 3 hari dengan denda keterlambatan Rp. 1000/hari

* Peminjaman buku umum dengan batas waktu 10 hari dengan denda keterlambatan Rp. 50 / hari

* Kamar mandi yang memadai

* Musholla yang representatif

2. Peningkatan nilai (value) jasa, performansi dan implementasi biaya yang diperoleh adalah :

\begin{tabular}{|c|c|c|}
\cline { 2 - 3 } \multicolumn{1}{c|}{} & \multicolumn{2}{c|}{ Alternatif Desain } \\
\cline { 2 - 3 } \multicolumn{1}{c|}{ Value } & Desain Awal & Desain Usulan \\
\hline $\begin{array}{c}\text { Peningkatan } \\
\text { Value }(\%)\end{array}$ & - & 1,045 \\
\hline Performansi & 45,799 & $4,5 \%$ \\
\hline $\begin{array}{c}\text { Peningkatan } \\
\text { Performansi } \\
(\%)\end{array}$ & - & 51,488 \\
\hline Biaya & Rp. 6.250 .000 & Rp. 6.725 .000 \\
\hline $\begin{array}{c}\text { Peningkatan } \\
\text { Biaya (\%) }\end{array}$ & - & $7,6 \%$ \\
\hline
\end{tabular}




\section{DAFTAR PUSTAKA}

Arikunto, Suharsimi, DR, Prosedur Penelitian, Suatu Pendekatan Praktek, Edisi Revisi

Dinama, Hendra. RS, Drs, 1996, Kusmijati, DR, Pedoman Mengelola Perpustakaan, Secara Praktis, Untuk Perpustakaan Sekolah Dan Perpustakaan Umum, Dwi Pratama Surabaya.

Gasperz, Vincent, 1998, Manajemen Kualitas Dalam Industri Jasa, Edisi Pertama BPFE - Yogyakarta.
Saifudin, Avwar, 1998, Sikap Manusia dan Pengukurannya, Edisi II, Pustaka Pelajar.

Singarimbun, Masri dan Effendi, Sofian, 1989, Metode Penelitian Survay, LP3ES.

Sudjana, M.A, Prof, DR, Msc, 1995, Desain dan Analisis Eksperimen, Edisi IV, Tarsito Bandung.

Zimmerman I.W. And Hart G. D, 1982, Value Engineering A Practical Approach For Own, Designer And Contractor, Van Hostland Reinhold Company, New York. 